\title{
Erratum to: Characteristics of Pharmacy Students Associated with a Successful PGY1 Residency Match
}

\author{
Agnes Feemster $^{1} \cdot$ Martin Calabrese $^{1} \cdot$ Priyanka Gaitonde $^{1} \cdot$ Fadia Shaya $^{1}$
}

Published online: 15 August 2017

(C) International Association of Medical Science Educators 2017

Erratum to: Med. Sci. Educ.

DOI 10.1007/s40670-017-0432-2

Martin Calabrese's name was originally misspelled in this article. It appears correctly here. The original article has been updated.

The online version of the original article can be found at doi: http://dx.doi. org/10.1007/s40670-017-0432-2

Agnes Feemster

afeemster@rx.umaryland.edu

1 School of Pharmacy, University of Maryland, Baltimore, MD, USA 